\title{
Animal welfare perspectives on recreational angling
}

\author{
Steven J. Cooke ${ }^{\mathrm{a}, *}$, Lynne U. Sneddon ${ }^{\mathrm{b}}$ \\ ${ }^{a}$ Institute of Environmental Science and Department of Biology, College of Natural Sciences, \\ Carleton University, 1125 Colonel By Drive, Ottawa, Ont., Canada K1S $5 B 6$ \\ ${ }^{\mathrm{b}}$ University of Liverpool, School of Biological Sciences, The BioScience Building, Liverpool L69 7ZB, UK
}

Available online 19 October 2006

\begin{abstract}
Fish captured by recreational anglers are often released either voluntarily or because of harvest regulations in a process called "catch-and-release". Catch-and-release angling is thought to be beneficial for the conservation of fish stocks based on the premise that most of the fish that are released survive. However, expanding interest in animal welfare has promoted debate regarding the ethics of catch-and-release angling. There is a growing recognition that fish can consciously experience nociception and that they have some capacity to experience pain and fear. Indeed, empirical anatomical, physiological, and behavioural evidence supports the notion that fish could experience these two forms of suffering (i.e., pain and fear). Based on that premise, we examine existing catch-and-release research from a welfare perspective to determine the extent to which potential pain and suffering could be caused. There are numerous studies that provide analyses of the consequences of catch-and-release on the individual demonstrating physical injury, sublethal alterations in behaviour, physiology, or fitness, and mortality. Collectively, this research suggests that all recreational fishing results in some level of injury and stress to an individual fish. However, the severity of injury, magnitude of stress, and potential for mortality varies extensively in response to a variety of factors. Interestingly, this information can be used to identify strategies that anglers may adopt that minimize these effects through changes in either gear (e.g., type of hook, bait, or net) or angling practices (e.g., duration of fight and air exposure, fishing during extreme environmental conditions, fishing during the reproductive period). Although aspects of the catch-and-release angling experience cannot be refined (e.g., the need to physically hook the fish), we argue that informed anglers and fisheries managers can adopt practices to improve the welfare of angled fish. Although consideration of fish welfare is somewhat abstract to most anglers and fisheries managers, ultimately it benefits the individual fish, while simultaneously benefiting the fish population and fishery. Greater integration of welfare consideration into recreational and commercial fisheries should promote innovative solutions to minimize pain and suffering, which should also enhance conservation and management.
\end{abstract}

(C) 2006 Elsevier B.V. All rights reserved.

Keywords: Angling; Conservation; Fish; Injury; Pain; Sportfishing; Stress; Welfare

\footnotetext{
* Corresponding author.

E-mail addresses: scooke@connect.carleton.ca (S.J. Cooke), 1sneddon@liverpool.ac.uk (L.U. Sneddon).
} 


\section{What is welfare?}

There are a number of definitions of welfare but these are disputed because the concept is complicated and the researchers cannot agree upon a common use of the term "welfare" (Dawkins, 1998; Appleby, 1999). There is a general agreement that welfare applies to well-being and that it assumes an animal is in optimum condition. Therefore, definitions of welfare are based upon physiological states or upon mental state, the latter being much more difficult to quantify. Definitions based on "feelings" are set in terms of subjective mental states that can only be measured indirectly (Spruijt, 1999). The animal should "feel" well for good welfare and be able to perform "natural" behaviours, without experiencing adverse events such as pain, fear or acute/ chronic stress. This definition of welfare is dependent upon the animal having conscious thought in that it should be able not only to perceive pain, but also know that it is in pain and suffering from it. Internal state or function-based definitions focus on the ability of an animal to adapt to its environment. Welfare is equated with health and physiological measures (and particularly those involved in coping with stress) and consequently they are used as indicators of the well being of the animal. Welfare can also be defined from a natural behaviour perspective whereby the animal has an innate suite of behaviours it should be allowed to perform for good welfare. Therefore, the animal must be provided with materials and appropriate habitat for it to express its natural behaviour. This definition of welfare can be quantified by comparing behaviour of animals in the wild to those kept in captivity.

\section{Welfare issues in fish}

Fish are subjected to a number of procedures in commercial (e.g., Chopin and Arimoto, 1995) and recreational fisheries (e.g., Cooke et al., 2002a; McPhee et al., 2002), aquaculture (e.g., Chandroo et al., 2004a,b; Conte, 2004), and scientific experimentation (e.g., DeTolla et al., 1995) which are invasive and may cause tissue damage that would give rise to pain in humans. Perhaps the most work to date on considering the welfare status of fish has been in the context of aquaculture (e.g., Chandroo et al., 2004a,b). For example, many aquaculture practices elicit physiological stress responses such as air exposure during vaccination in fish farms (review in Conte, 2004) and thus compromise the well-being of fish. Studies have quantified the internal state of fish by measuring a variety of physiological indicators and come to the conclusion that fish welfare may be impaired during these practices (see below and Conte, 2004). In recreational fisheries, some fish are harvested, but many more are released (i.e., catch-and-release angling). To date, there have been few attempts to incorporate animal welfare principles into recreational fishing guidelines and practices (for either catch-and-release and catch-and-harvest). In fact, we really no quite little about the possible pain, suffering, or other negative consequences associated with recreational angling. To understand the impact of the procedures to which we subject fish, we must evaluate the physiological and behavioural effects of such events upon the welfare of fish. It is vital from a welfare perspective to understand the impacts of our actions so that we can find ways of improving these practices and thus enhance the well-being of the fish.

The physiological and behavioural responses to a potentially adverse event such as one that may cause pain, fear and stress can be relatively easily measured (Zimmerman, 1986). However, the subjective experience of the fish or the emotional state of the fish is impossible to measure with current technology. Essentially this means we cannot get inside of the fish's mind and know exactly what it experiences. Unless one has been a fish, how do we know what it experiences? In our review we give fish the benefit of the doubt in that, if the fish shows adverse physiological and 
behavioural responses that are comparable to those shown by mammals or humans, then there is the potential for the fish to experience a negative event in the same way. This leads to the controversial question of suffering - i.e. the fish may be capable of detecting pain and reacting to it but does it know it is in pain and does it suffer. Literature covering this point has reviewed a variety of studies and some argue that fish experience pain and can suffer (e.g. FSBI, 2002; Chandroo et al., 2004a,b), however, one review disputes this interpretation (Rose, 2002). Critics have argued that fish lack essential brain regions or any functional equivalent, making it untenable that they can experience pain and fear (Rose, 2002), whilst others suggest that there is anatomical, physiological, and behavioural evidence that makes it conceivable that nociception in fish is consciously experienced and that they have some capacity to experience pain and fear (Chandroo et al., 2004a,b). Empirical evidence from studies designed to examine pain and fear in fish has also produced significant evidence for the ability of fish to experience these two forms of suffering (Sneddon et al., 2003a,b; Sneddon, 2003a,b, 2004; Portavella et al., 2002; Yue et al., 2004). Rather than a comprehensive review of all fish welfare issues, this review focuses on the impacts of catch-and-release recreational fishing, which is economically important and possibly plays a significant role in conservation (McPhee et al., 2002). We discuss the evidence for pain in fish and discuss what the consequences of catch and release are upon the welfare of released fish.

\section{The question of pain in fish}

There has been much controversy over the topic of pain in fish with conflicting views adopted by different public groups. Indeed, a recent review of pain in fish concluded that they were not capable of pain since they lacked a neocortex (Rose, 2002). Given that most mammals, birds, and amphibians lack a neocortex this suggests that they also do not experience pain. Yet many scientific studies have amply demonstrated pain and suffering in these groups (e.g. birds, Gentle, 1992; amphibians, Stevens, 1992). Therefore Rose's (2002) definition of pain is anthropomorphic since it limits the perception of pain to only humans and non-human primates. The opposite view is that fish are potentially capable of experiencing pain because nerves that convey pain information in humans are also found in the rainbow trout, Oncorynchus mykiss, a model teleost (Sneddon, 2002; Sneddon and Gentle, 2002). Further studies used electrophysiological techniques to examine the properties of receptors on the head of the trout (Sneddon, 2003a). Five types of receptors were found and of these $35 \%$ were nociceptors and were located on the head, lips and opercular area of the trout (Fig. 1). The trout nociceptors were identical in their physiological properties compared with mammalian nociceptors (Sneddon, 2003a; Sneddon et al., 2003a). These data strongly support the hypothesis that the rainbow trout is capable of nociception and the detection of tissue damage and potentially painful stimuli. Studies are also addressing the importance of higher brain centres in processing potentially painful information. Dunlop and Laming (2005) have demonstrated that there is substantial nerve activity in the brain including the cortical areas during noxious stimulation in goldfish and rainbow trout and recent data on gene expression has shown that most expression changes occur in the forebrain where the fish cortex is situated (Reilly and Sneddon, unpub. data). These studies show the brain is active at both the molecular and physiological level during potentially painful stimulation. If these were simply nociceptive reflexes as Rose (2002) claims, there would be no or minimal activity in the brain.

To explore whether pain perception occurs in the trout, in vivo experiments examined the effects of acutely acting painful substances injected into the lips of the rainbow trout upon subsequent behaviour and respiration rates (Sneddon et al., 2003a). The injected fish were 


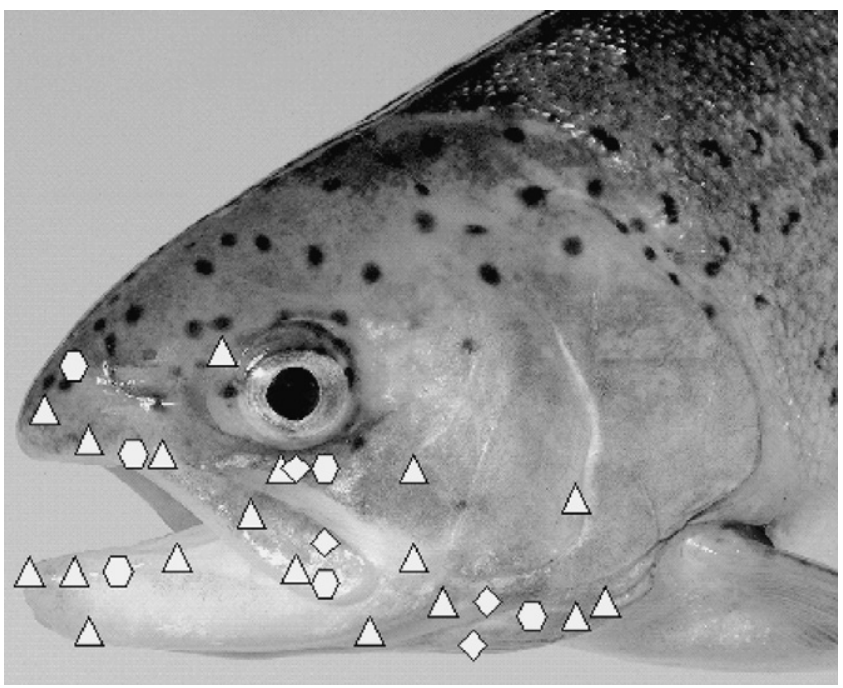

Fig. 1. Location of the nociceptors and chemical receptors on the head of the trout $(\triangle$, polymodal nociceptor; $\diamond$, mechanothermal nociceptor; $\square=$ mechanochemical receptor; from Sneddon et al., 2003a).

compared with saline injected fish and handled controls. The noxiously treated fish exhibited behavioural and respiratory effects over a prolonged period of time, approximately $3 \mathrm{~h}$. Also, noxiously stimulated fish took longer to resume feeding (180 min compared with controls at $80 \mathrm{~min}$ ) and performed anomalous behaviours such as rocking on the gravel substratum and rubbing the lips into the gravel and against the sides of the tank. These behaviours could be taken to indicate suffering as they have in other vertebrate species (Kato et al., 2001; Roveroni et al., 2001; Molony et al., 2002). Respiration rate, measured as opercular beat rate, almost doubled in noxiously stimulated individuals (52-98 beats/min) whereas controls showed a typical stress induced increase to only 68 beats/min. These high respiration rates in the noxious group are similar to rates recorded when the rainbow trout is at its maximum sustained swimming speed and so these injected fish are ventilating at a high rate indicating the dramatic effect of noxious stimulation (Laitinen and Valtonen, 1994). Increased respiration rates are also exhibited by higher vertebrates when they experience a painful event (Kato et al., 2001). These effects of noxious stimulation (dramatic rise in opercular rate; performance of anomalous behaviours) were ameliorated when an analgesic, morphine, was administered which specifically blocks the action of nociceptors (Fig. 2, Sneddon, 2003b). These results indicate that the behavioural and physiological responses to noxious stimulation are complex and this is consistent with the involvement of higher central processing. Therefore, a painful event had a profound influence on behaviour and the performance of anomalous behaviours in the natural environment might make the fish more conspicuous to predators. Foraging behaviour was also affected such that fish did not resume feeding until the effects of the acutely painful substances subsided. If a painful event, such as a serious injury, persisted for an ecologically relevant period of time then growth of the fish may be negatively affected and this may have an impact on reproductive output and survival. More research is needed to investigate the behaviour of fish in the wild after a potentially painful event.

A psychological aspect to the fish's experience must be demonstrated since pain consists of both a sensory and psychological component. Therefore, a selective attention strategy was used 

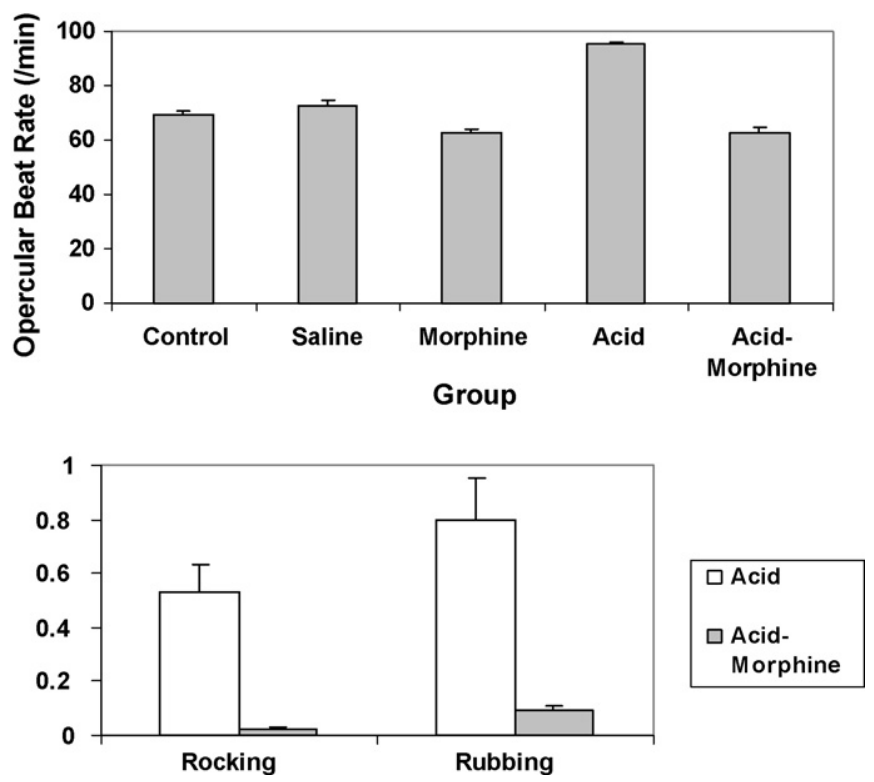

Fig. 2. (A) The effects of morphine (ACID MORPHINE) on opercular beat rate after administering a noxious chemical, $0.1 \%$ acetic acid (ACID) to the lips of the trout. Values are also shown for handled controls, saline injected fish and for fish treated with morphine only. (B) The effects of morphine administration on the frequency of rocking to and fro on the substrate and the frequency of rubbing the lips (Adapted from Sneddon, 2003b).

to try and divert attention away from the pain. If successful, this would indicate that the experience is relatively unimportant to the fish. One of the major theoretical perspectives on attention is that there is a limited capacity or pool of attention and that pain may take priority, or "soak up", a large amount of this pool, leaving little capacity for competing stimuli (Kuhajda et al., 1998). Results from animal models have suggested that diverting attention towards a novel stimulus reduces pain-related behaviours (e.g. mice, Kavaliers and Colwell, 1991; birds, Gentle, 2001). This prompted a more psychological approach exploring how the rainbow trout experiences pain (Sneddon et al., 2003b). It is suggested that the motivational state induced by processing of pain is dramatically attention-demanding and attention cannot be diverted away from pain when the pain is severe (Kuhajda et al., 1998). Rainbow trout were tested to examine their fear response to a novel object when subject to noxious stimulation (Sneddon et al., 2003b). Control fish showed a classic neophobia and avoided the novel objects whereas noxiously stimulated fish showed no aversion and spent the majority of their time in close proximity to the object. This suggests that the painful experience dominated the fish's attention and so they failed to show an appropriate fear response. Therefore, a painful event interfered with the performance of normal behaviour. If the trout were to react to a predator as it did to the novel object it is likely that it would be caught and eaten, although this remains to be tested.

This work on the rainbow trout collectively calls for a reassessment of the concept of pain as applied to lower vertebrates. Accepting this evidence means that procedures commonly performed in fisheries and aquaculture need to be examined to determine the extent to which pain and potential suffering is caused. Freedom from pain is essential for the welfare of an animal and, ethically, we have a responsibility to ensure that animals in our use are treated humanely. Several such examinations now exist for aquaculture (Chandroo et al., 2004a,b; Conte, 2004), but a similar 
review evaluating recreational angling is absent. In fact, there are no scientific papers that integrate catch-and-release issues with animal welfare. Similarly, a large online repository of research on fish welfare issues has surprisingly little in the way of catch-and-release information (Erickson, 2003). Although frequently discussed and hotly debated in public forums (e.g., Randerson, 2003), we provide the first scientific perspective on the welfare issues associated with recreational angling.

\section{Recreational angling}

\subsection{Definition and scope}

Recreational fisheries are usually considered those where fishing is conducted by individuals for sport and leisure, with a possible secondary objective of catching fish for personal consumption (FAO, 1997; Pitcher and Hollingworth, 2002b). Sometimes this definition also includes the selling of surplus catch to offset costs (Cowx, 2002). Cowx (2002) refined the FAO (1997) definition to categorize anglers into four main types; leisure fishing, match (e.g., competitive angling events, derbies, tournaments) fishing, game fishing, and specimen or specialist fishing. Angling has become an important recreational activity for people around the globe, generating substantial income for regional and national economies (Pitcher and Hollingworth, 2002a). Cooke and Cowx (2004) estimate that recreational harvest may exceed 10 million metric tonnes (compared to over 80 million tonnes in the commercial sector). The authors also estimate that nearly $12 \%$ of the worlds' population engages in recreational fishing on a regular basis, although participation rates vary widely among countries.

\subsection{Catch-and-release}

As indicated above, some anglers retain and harvest fish for consumption. However, other anglers release some component of their catch for various reasons. Fish are typically released if they are not the intended targets or are undesirable (wrong sex, wrong size, questionable food value). In some jurisdictions, regulations are in place that mandate release of some or all fish (e.g., certain species, sizes) in an attempt to conserve fisheries resources (Quinn, 1996). Recreational fisheries also include significant voluntary catch-and-release behaviours where anglers release fish for "ethical", conservation, or sporting reasons, never with the intention of harvesting individuals (e.g., the assumption that the released fish will survive to be caught again in the future; Quinn, 1996; Aas et al., 2002; Policansky, 2002). The history of catch-and-release angling is covered in detail elsewhere by Policansky (2002) and Radonski (2002) and is beyond the scope of this paper. Whatever the reason behind why fish are released, it is estimated that recreational release rates are at or near $60 \%$ (e.g., United States Department of Commerce, 2002; Department of Fisheries and Oceans Canada, 2003), suggesting that globally more than 30 billion individual fish are returned to the water each year (Cooke and Cowx, 2004).

There has been much debate about the ethics of recreational fishing, and in particular catch-andrelease (e.g., de Leeuw, 1996; Chipeniuk, 1997; List, 1997; Balon, 2000). In some jurisdictions such as Germany, all fish captured by anglers must be retained in accordance with animal welfare regulations (Hickley, 1998; Steffens and Winkel, 2002; Aas et al., 2002). In fact, in several European countries welfare of fish exposed to recreational angling ranks as important whereas in other European jurisdictions it is perceived as an ethical and conservative approach to resource use (Aas et al., 2002). In other regions (e.g., North America, Australia) catch-and-release is advocated by conservationists and is an institutionalized component of fisheries management (Aas et al., 
2002). There is no doubt that in recent years the issue of fish welfare in the context of recreational fishing has become a heated topic and created public discourse in almost all regions (Spitler, 1998). Nonetheless, recreational fishing is a widely popular activity and has also developed into a prosperous industry providing immense benefit to society and economy (see; Hickley and Tompkins, 1998; Pitcher and Hollingworth, 2002a).

For our purposes, we will not differentiate among the reasons why fish are released and simply recognize that there is much controversy on this topic. That said, we would like to acknowledge that the "selective harvest" approach advocated in recent years (e.g., Quinn, 1993; Stange, 2003) is a more balanced approach that enables anglers to make decisions (as guided by ethics, needs, laws, etc.) about whether an individual fish is to be released (rather than releasing all fish). Even those that would argue recreational fishing should only be done to collect food must logically recognize that not all fish captured should be harvested and that it is challenging for anglers to target a specific fish with the desired characteristics (e.g., the smallest fish, certain species, the largest fish, rare fish, etc.). Similarly, not all fish should be released since anglers must make decisions about injuries, stress, and mortality potential while considering the welfare of the fish if it were to be returned to the waters.

Fish that are harvested for food are generally killed rapidly, and assuming that the fishery is sustainable (and legal), such harvest is an accepted practice. There is much debate about the consequences of fish that escape prior to capture (dropoffs) or those that are captured and later released. An unknown proportion of fish captured by anglers and released under the assumption that they will survive, die post release (Muoneke and Childress, 1994) or experience long-term sublethal disturbances that affect the welfare or fitness of the individual (Cooke et al., 2002a). There are a number of simple and effective strategies that are employed to minimize these negative effects. Here, we briefly review some of those factors and discuss them in the context of improving the welfare of individual fish that are captured and released. Other treatments of this topic have focused more on population level impacts that are seen as directly relevant to fisheries managers (Wydoski, 1977). We contend that improving the welfare status of individual fish will provide benefits to populations. There are clearly a number of advances in gear technology and angler practice that can lead to more sustainable and ethical recreational fisheries. For the purposes of this paper, our efforts will focus on recreational fisheries that use hook and line, generally with a rod.

\section{Individual based effects of recreational angling}

There are three primary negative consequences that can arise from angling which may include exposing fish to painful situations or otherwise affect welfare status: (1) sublethal physical injury, (2) sublethal stress, and (3) mortality. These negative consequences of angling are not necessarily independent - for example, most mortality is preceded by either severe injury or stress (and often both). Here we discuss the sublethal injuries and stress, and then consider mortality separately. This is not an exhaustive review of all topics (e.g., such as hooking mortality where there are now many studies). Instead, we summarize some of the key literature, emphasizing recent developments, and attempting to provide a balanced overview (i.e., illustrating contradictory findings) of our state of knowledge.

\subsection{Physical injuries}

One topic rarely discussed is sub-lethal physical injury. There is no doubt that when a hook penetrates the flesh of a fish that there will inevitably be some form of tissue damage or injury, the 
extent of which is dependent upon anatomical location, type of gear, etc. In general, the majority of fish are hooked in the "jaw" region (Muoneke and Childress, 1994). This area is important for respiration (ventilation), food acquisition and consumption, and in some cases for reproduction (e.g., mouth brooding, competition for mates) or social interactions (e.g., yawning, displays). There are no scientific reports of the long-term consequences of jaw injuries. Meka (2004) noted that 29\% of rainbow trout captured in a study in Alaska exhibited signs of previous capture and more than $60 \%$ of the fish captured in their study received one or more significant injuries from that angling event. Another study on stream salmonids (rainbow trout, brown trout, Salmo trutta, and brook charr, Salvelinus fontinalis) in Wisconsin found previous jaw injuries on $6 \%$ of the captured fish (DuBois and Dubielzig, 2004). Another common location for sublethal injuries is the eye, resulting from damage during hooking and handling (e.g., Cooke et al., 2003; DuBois and Kuklinski, 2004). In fact, DuBois and Dubielzig (2004) reported that $10 \%$ of stream salmonids landed experienced severe eye damage that was likely to cause long-term or permanently impaired vision. Lost or impaired vision in one eye does not imply that death is imminent, although it has been linked to mortality (Warner, 1976; Pauley and Thomas, 1993). However, individuals may suffer a fitness impact associated with finding prey, avoiding predators, or securing a mate. At present there are no long-term assessments of visual impairments on the growth or fitness of fish. Unfortunately, there seem to be few clear patterns associated with gear type or bait choices that reduce eye related injuries (DuBois and Dubielzig, 2004).

Sublethal injury can also occur in the throat, esophagus, or gut from removal of hooks or leaving them in place. Some fish are capable of expelling hooks that are left in place in due course. For example, a recent study revealed that recapture rates were similar between fish where hooks were left in versus those removed for 27 species in Australia (Wilde and Sawynok, unpublished data). Diggles and Ernst (1997) reported that several fish were able to expel hooks during a post capture holding period. Aalbers et al. (2004) reported that survival was enhanced in white seabass, Atractoscion nobilis, when deep hooks were left in, but this affected growth rate. Similar results were reported by Schisler and Bergersen (1996) for rainbow trout. Schill (1997) reported that $60 \%$ of deeply hooked wild rainbow trout were able to expel hooks. When targeting powerful marine pelagics, many of which have sharp teeth, it is common to lose many fish (i.e., break fishing line). Borucinska et al. (2001) found that a retained fish hook in a single blue shark, Prionace glauca, lead to pathogenic peritonitis and pericarditis. In a more exhaustive survey, Borucinska et al. (2002) found retained fishing hooks from previous capture events in 6 of 211 blue sharks off Long Island New York. The hooks were embedded within the oesophagus or perforated the gastric wall and lacerated the liver. Collectively, tissue damage leads to lesions including oesophagitis, gastritis, hepatitis and peritonitis. There is a need for additional research prior to providing advice to anglers and managers on whether removing hooks or leaving them in is the best approach-this may differ on a case-by-case basis.

In addition to potential injury from hooks, other gear can also cause injury. For example, landing nets are commonly used in recreational fishing to retrieve fish from the water whilst decreasing mechanical strain on the fishing rod (Quinn, 1993; Barthel et al., 2003). Injuries (e.g., scale and mucous loss, fin fraying) are sustained from the abrasion of netting in landing nets that can lead to opportunistic infections and mortality (Barthel et al., 2003). Various types of nets are available, and these can cause differing amounts of dermal disturbance and fin abrasion. When testing different types of net mesh, Barthel et al. (2003) found that knotted mesh types were more injurious and led to higher mortality rates than rubber or knotless meshes. Similarly, use of other gear for retaining fish such as keep nets and stringers also cause injury (Pottinger, 1997; Cooke and Hogle, 2000). 
Apart from the obvious welfare consequences of damage and pain associated with physical injuries, their behaviour may be impaired and this could lead to increased susceptibility from predation (Cooke and Philipp, 2004), passive displacements from territories (Thorstad et al., 2003), and a temporary reduction in feeding (Siepker, 2004). In practical terms, research should be directed towards establishing the most welfare-friendly types of fishing gear to minimize the incidence and degree of injury.

\subsection{Sublethal stress and impairments}

In addition to physical injuries, there can also be a suite of sub-lethal physiological, behavioural, and fitness impairments that can arise from catch-and-release angling (see Cooke et al., 2002a). Although some information exists on how angling related stress might induce mortality (Wood et al., 1983), few studies have focused on what sublethal stress means to the organism, especially in relation to long-term individual fitness (Cooke et al., 2002a). When exposed to recreational angling, fish experience a suite of physiological alterations that require extended recovery periods. The magnitude of the stress can be influenced by a number of factors including the duration of the angling event (e.g., Gustaveson et al., 1991; Schreer et al., 2001; Thorstad et al., 2003), the water temperature at the time of angling (Wilkie et al., 1996, 1997), and the length of air exposure (Ferguson and Tufts, 1992; Cooke et al., 2001).

When first hooked, fish release catecholamines as part of the "fight or flight response" (Mazeaud et al., 1977). This primary stress response stimulates a number of secondary responses. When assessing stress associated with catch-and-release angling, it is usually the secondary responses that are evaluated. These secondary physiological disturbances typically include white muscle imbalances (i.e., accumulation of lactate and depletion of tissue energy stores; Kieffer et al., 1995; Suski et al., 2004) and hematological alterations (e.g., acid/base imbalances, hydromineral imbalances, accumulation of metabolites; Wells et al., 1986; Gustaveson et al., 1991; Kieffer et al., 1995; Wilkie et al., 1996, 1997) associated with anaerobic activity. Furthermore, the cardiorespiratory system also experiences changes reflecting the heightened physical activity and resultant increased tissue oxygen demands (or repayment of oxygen debt; Schreer et al., 2001; Cooke et al., 2004). We do not know, however, if these responses are indicative of pain or are themselves painful, but they do reflect a stress response. The responses exhibited by fish when angled are the same as those experienced by fish when exposed to exercise in other settings (Kieffer, 2000) but are typically magnified by additional handling or other factors that the angler can control (e.g., air exposure). A fish cannot be captured or handled by a recreational angler without exposing the fish to stress thus representing a clear impact on the welfare status of the individual. However, knowledge of the specific factors responsible for stress provides the opportunity to develop strategies to minimize the magnitude and effects of the stress, improving the welfare of the fish and the sustainability of the fishery.

Although we know little about whether a stressed state indicates pain, both acute and chronic stress can have negative effects (known as tertiary effects that arise from the primary and secondary stress responses) such as suppressing immune responses (Mazeaud et al., 1977), retarding growth (Pankhurst and Van Der Kraak, 1997), or reducing fitness (Pankhurst and Van Der Kraak, 1997). These general principles are well known in the aquaculture literature (see Iwama et al., 1997) but have only recently been investigated in a catch-and-release context. For example, a recent study on largemouth bass, Micropterus salmoides, revealed that exposure to a simulated fishing tournament prior to spawning reduced the quantity and quality of the offspring that survived (Ostrand et al., 2004). Parental black bass removed from nests during parental care 
exhibit white muscle disturbances (Kieffer et al., 1995) and associated locomotory impairments (Cooke et al., 2000) that reduce nest guarding and aeration activity, often leading to nest abandonment (Kieffer et al., 1995; Philipp et al., 1997). Earlier work on rainbow trout revealed that stress associated with capture was sufficient to suppress reproductive hormones and thus negatively affect reproduction (Pankhurst and Dedual, 1993). In another experiment, Siepker (2004) documented feeding impairments post-angling and then used bioenergetic models to predict the longer-term consequences of the reduced feeding activity on growth. Bioenergetic simulations for striped bass, Morone saxatilis, showed similar patterns to those observed by Siepker (2004) in that fish exposed to angling experienced reduced growth (Stockwell et al., 2002). We do want to caution that these types of studies are still rare and that there are also examples where no growth impairments (e.g., Pope and Wilde, 2004) or fitness effects (e.g., Booth et al., 1995) have been observed.

\subsection{Mortality}

Since most fish that die from catch-and-release angling do so some time (minutes to weeks) after release (Muoneke and Childress, 1994), some anglers and fisheries managers assume that mortality arising from catch-and-release angling is negligible. Although this may be the case for some species, others may indeed experience high, often unnoticed, levels of mortality. In a review of hooking mortality studies, Muoneke and Childress (1994) reported that mortality rates for released fish ranged from $0 \%$ to $89 \%$ across many marine and freshwater species. Hooking mortality is usually divided into immediate/initial and delayed mortality. Immediate/initial mortality is defined as death during or following capture, but prior to release. Delayed mortality represents death from catch-and-release angling at some point after the released fish swims away; this mortality is usually determined by holding fish in cages, pens, or hatchery ponds. Total hooking mortality is the sum of initial and delayed mortality minus the cross-product of initial and delayed mortality (see Wilde et al., 2003). The processes that lead to immediate and delayed mortality are potentially painful for fish. In a welfare context, extended suffering prior to delayed mortality would be undesirable, emphasizing the important role that anglers play in assessing the likelihood that a fish will die if released. A major synthesis by Muoneke and Childress (1994) compiled studies on hooking mortality for both marine and freshwater fish and suggested that total hooking mortality estimates above $20 \%$ should generally be considered unacceptably high.

A number of factors are associated with mortality, but the two primary ones are physical injuries (largely from gear and handling) and the cumulative effects of numerous stressors (mediated by handling, water temperature, sex, size, etc.). Some severe injuries can occur during capture and almost always result in death (these fish should not be released). Examples include any injury that results in blood loss to the point that gills become pale and the fish loses perfusion of fin tissues. These injuries most commonly arise from damage to the cardiorespiratory structures such as the gills or heart (e.g., Pelzman, 1978; Savitz et al., 1995; Prince et al., 2002; Lindsay et al., 2004). There are no absolutes when dealing with fish as to whether or not an individual will survive so anglers need to make decisions (selective harvest) about which individuals are most likely going to die within hours and thus should be dispatched rather than released.

Also potentially important is mortality of fish that escape from the hook before being brought to the boat or fish that are removed from the hook by predators, so-called "drop offs". Lawson and Sampson (1996) developed a model that suggests in the overall mortality, drop-off mortality could be as important as hook-and-release mortality. Measuring this type of mortality is challenging. 


\section{What can be done to improve welfare of angled fish?}

Knowing that most injuries are attributed to gear and most stressors attributed to angling practices, there are a number of simple strategies that have been proposed to reduce the level of injury/disturbance and hence mortality. It is these same strategies that have the potential also to improve the welfare of fish that are angled and released. A recent synthesis by Cooke and Suski (2005) suggested that there were five specific actions that anglers could take to minimize negative consequences on fish. Briefly, we discuss each of those strategies in the context of welfare. This list is not exhaustive as there are many factors that affect mortality, stress, and injury so we do not intend to constrain anglers or managers to these possible improvements. Instead, this is intended to serve as a general guide. We also acknowledge that it is difficult to generalize (see discussion in Cooke and Suski, 2005) and that there are many exceptions. Nonetheless, these guidelines should provide a starting point for addressing welfare of angled fish.

\subsection{Minimize angling duration}

Once hooked, fish are exposed to exhaustive exercise, which results in physiological alterations. In general, the current body of catch-and-release research suggests that the duration of the actual angling event experienced by the fish correlates positively with the magnitude of physiological disturbance and the time required for recovery (Gustaveson et al., 1991; Kieffer et al., 1995; Schreer et al., 2002; Thorstad et al., 2003). Angling is essentially a combination of aerobic and anaerobic exercise that results in a series of physiological changes including a depletion of energy stores and an accumulation of lactate, as well as acid/base changes and osmoregulatory disturbances (Wood, 1991). We suggest that fish welfare would be best served if fish were landed as quickly as possible to minimize the duration of exercise and the concomitant physiological disturbance. Techniques for achieving short duration angling events are generally focused on choice of equipment. Anglers should chose optimal equipment matched to the size of fish that are expected to be encountered. There is substantial evidence supporting the notion that the size of fish is positively correlated with the duration of the angling event (Thorstad et al., 2003; Meka and McCormick, 2005). Efforts to intentionally prolong the angling event through the use of light line or rods should be dissuaded as this would not be consistent with the notion of improving animal welfare.

\subsection{Minimize air exposure and improve handling}

A growing body of literature has revealed that air exposure is one of the most stressful components of the entire catch-and-release angling experience for a variety of different taxa (e.g., rainbow trout, Ferguson and Tufts, 1992; rock bass, Ambloplites rupestris, Cooke et al., 2001; smallmouth bass, Micropterus dolomieu, Cooke et al., 2002a; largemouth bass, Suski et al., 2004). Air exposure leads to collapse and adhesion of gill filaments as well as substantial metabolic disturbances (Ferguson and Tufts, 1992; Cooke et al., 2001). During air exposure fish often struggle and unsuccessfully attempt to draw water over their gills but only receive "air" from which they cannot extract oxygen when out of water. The welfare of fish captured by anglers (and indeed all fish handled in fisheries science, aquaculture, commercial fisheries, etc.) would benefit immensely from simply leaving fish in the water. Hooks can be removed and photographs taken while either eliminating or minimizing (several seconds) air exposure. Reducing air 
exposure is an indisputable recommendation (e.g., Ferguson and Tufts, 1992; Cooke et al., 2001) that will surely improve fish welfare.

Similarly, when landing fish, anglers have the opportunity to use different gears such as nets. Barthel et al. (2003) revealed that nets are more injurious than landing fish by hand, but if a net must be used, they recommended that anglers should use those that do not abraid the fish such as knotless nylon or rubber. Also, some anglers retain fish for short periods, usually associated with competitive fishing events. We strongly discourage use of any stringers as they can cause major injury (Cooke and Hogle, 2000) and instead recommend livewells or coolers if retention is necessary. Fish retained in livewells or coolers should be provided with adequate water quality so that the retention period is minimally stressful. Indeed, when provided with adequate oxygen (Suski et al., 2004) and held at low densities (Cooke et al., 2002b), retained fish can actually recover from the angling and handling (Cooke et al., 2002b; Suski et al., 2004) so that when released they are in good condition (or at least one can better assess their condition and evaluate whether they should be released). In Europe keep nets are popular and have been shown to have minimal effects on cyprinid mortality or stress (e.g., Pottinger, 1997; Raat et al., 1997). However, a Canadian study revealed that keep nets caused serious injury in smallmouth bass (Cooke and Hogle, 2000). Based on potential for injury demonstrated by Barthel et al. (2003) and Cooke and Hogle (2000), keep nets seem to be less desirable than coolers or livewells.

\subsection{Terminal tackle choices can affect fish}

Anglers make choices (or governments mandate gear use) about what kind of tackle they will use. These choices deal with the kind of hooks and baits/lures/fly. Choices are driven by the species and mode of fishing but in general anglers have the opportunity to make choices that will reduce mortality potential, decrease handling time (and sublethal disturbances) and reduce injury. The simplest example is the use of barbless hooks. Barbless hooks are easier to remove than barbed hooks (Diggles and Ernst, 1997; Schaeffer and Hoffman, 2002; Cooke et al., 2001; Meka, 2004) resulting in reduced air exposure time (Cooke et al., 2001). Furthermore, they tend to cause less tissue damage (Meka, 2004). Interestingly, the suggestion that barbless hooks are beneficial relative to barbed hooks has generated controversy because the literature accounts are contradictory (e.g., Taylor and White, 1992; Schill and Scarpella, 1997; Turek and Brett, 1997). Nonetheless, we argue that less tissue damage and more rapid hook removal are both consistent with improving the welfare of angled fish as well as improving their chances of survival.

Anglers can also make choices between different hook designs such as circle hook versus more conventional "J" style hook. Circle hooks tend to result in shallower hooking and reduce mortality by $50 \%$ (see review by Cooke and Suski, 2004) relative to J style hooks. However, this pattern does vary among species. Circle hooks also are more difficult to remove and can cause more tissue damage relative to a $\mathrm{J}$ hook in the same anatomical location (Cooke and Suski, 2004). However, a barbless circle hook may be a good alternative as the circle shape would help to reduce losses during the fight and the lack of barb would expedite removal.

Choice of bait can also be important. Single hook flies tend to produce less injury (and mortality) than do organic baits (e.g., worms, baitfish, dough) or lures with treble hooks (see Muoneke and Childress, 1994; Schisler and Bergersen, 1996). However, organic baits can be more detrimental than lures (e.g., Diggles and Ernst, 1997; Wilde et al., 2000). Interestingly, Dunmall et al. (2001) found that use of scented baits, organic baits, or inorganic baits did not influence injury or mortality. Despite disparate findings, in general, artificial lures, and especially flies, should be better choices for the welfare of the fish. Of course avoiding use of live bait, and in 
particular vertebrates (e.g., frogs, baitfish), is also better for the welfare of those animals. Gear performance varies extensively by species but these recommendations do provide some general guidance for anglers when making decisions about terminal tackle.

\subsection{Avoid angling in extreme environmental conditions or habitats}

Each species is confined to a range of environmental conditions that determines where a fish may be distributed in space and time. Water temperature is an example of such a factor and has actually been described as the "master" factor as it plays such an important role in the physiology, behaviour, and ecology of fish (Fry, 1971). As fish begin to approach the upper or lower extremes of their range of thermal tolerances, they become more sensitive to other disturbances. Exercise and handling such as that which occurs during catch-and-release angling can be particularly detrimental during these conditions often leading to significant physiological disturbance (Wilkie et al., 1996, 1997; Schreer et al., 2001) or mortality (e.g., Wilde, 1998; Thorstad et al., 2003). Recognizing this, some fisheries are now managed in a way such that recreational fishing is prohibited when water temperature exceeds some biologically relevant threshold (e.g., this is common for Atlantic salmon, Salmo salar, in Newfoundland, Canada; Anderson et al., 1998; Wilkie et al., 1997). In instances where this is not regulated, anglers can still make informed decisions about when to angle if they understand the important mediating role of water temperature. By educating anglers on the environmental relations of fish, anglers will be better informed about how to minimize distress and improve welfare of angled fish.

Fish captured at depth also typically face challenges that are relevant to their welfare (Kerr, 2001). When brought to the surface rapidly, the gasses in swimbladders of physoclistous fish rapidly expand to the point that the fish are unable to achieve neutral buoyancy, maintain equilibrium, and may even have their stomachs protruding from their mouths (Burns and Restrepo, 2002) in addition to embolisms and blood-gas disturbances that are not as clinically obvious (Morrissey et al., 2005). Different species respond to capture at depth differently and each also has their own threshold regarding which depths are problematic. In this case, avoiding fishing in deep water or releasing fish immediately before the gasses expand are good options. Additionally, anglers can vent the swimbladder with a needle to release the gas and enable the fish to swim back to depth (Keniry et al., 1996; Collins et al., 1999; Kerr, 2001; Burns and Restrepo, 2002). Although venting can enhance survival, the effects of the venting procedure on an individual's physiology or its potential for inflicting pain is unknown and as such has been discouraged (Kerr, 2001). This research topic requires more work before definitive answers can be provided.

There are also locations where there are extreme levels of predators. Predation is of course a natural process, but when released fish are being selectively preyed upon, this can create additional mortality. For example, Cooke and Philipp (2004) revealed that in some areas where shark abundances were high, released bonefish (Albula spp.) were often consumed by sharks. Simply relocating to another area could remedy this problem. An alternative strategy is to retain fish for a short period in a livewell or cooler (provided with adequate water quality) and then release the fish when more recovered or in a safer environment.

\subsection{Avoid angling during the reproductive period}

To date, there has been little research on the fitness implications of catch-and-release angling. However, it is clear that sublethal fitness impacts can arise from angling (see Cooke et al., 2002a for review; e.g., Pankhurst and Dedual, 1993; Philipp et al., 1997; Cooke et al., 2000; Ostrand 
et al., 2004; but see Booth et al., 1995; Lowerre-Barbieri et al., 2003 for examples where no impacts were observed). As such, Cooke and Suski (2005) believed that it was a logical recommendation to avoid fishing during the reproductive period. The intention behind their recommendation was that if fish were unable to reproduce, then populations would be directly impacted upon and that reproduction is sufficiently finite period that such a change in angler behaviour would be minimally disruptive. The direct welfare implications are less clear in this case as it deals more with an ethical issue as to whether it is acceptable to interfere with an animal during reproduction. Nonetheless, it is likely that avoiding angling during the reproductive period is good for individual welfare and fitness.

\section{Killing fish for harvest}

Although the focus of this paper is on catch-and-release angling, some proportion of the catch is often retained for harvest. Even the most ardent catch-and-release angler will occasionally need to kill fish that have been badly injured. There has been much work in the aquaculture industry on the development of humane slaughter methods that are relevant to recreational anglers (e.g., Robb and Kestin, 2002; van de Vis et al., 2003). Optimal slaughter methods should render fish unconscious until death without avoidable excitement, pain or suffering prior to killing (van de Vis et al., 2003). Percussion stunning (i.e., hitting the fish on the head with an object such as a rock, preacher, or stick) is likely the most common method used by anglers to dispatch fish (Cooke, Personal Observation). If done swiftly and the percussion is delivered to the appropriate region, this method is considered humane as it results in immediate loss of selfinitiated behaviour and loss of consciousness within several seconds (van de Vis et al., 2003). In reality, the stunning procedure is often not immediate and fish are hit multiple times (Wall, 2001). In the aquaculture industry, pneumatic guns have been developed to deliver the percussion but this is impractical for angling. Instead, a rigid club is probably the most appropriate tool for recreational anglers to use for percussive stunning. Other methods used by recreational anglers to kill fish include decapitation, exsanguination (i.e., bleeding out) through a gill cut, live chilling and freezing, asphyxia (air exposure), or hypoxia/anoxia (leaving fish in water bath without sufficient oxygen). All of these methods have been deemed to be less optimal than percussion stunning by the aquaculture industry (Robb and Kestin, 2002; van de Vis et al., 2003) and should thus be avoided by anglers.

\section{Developing welfare guidelines for anglers}

We hope that the material presented in this review will serve as the basis for welfare guidelines for angled fish. Current scientifically based fish welfare guides have not explicitly considered the welfare aspects of recreational fishing, although their general principles are often relevant (e.g., DeTolla et al., 1995; FSBI, 2002; AFS/AIFRB/ASIH, 2004). For anglers, fish welfare guidelines are sometimes presented in codes of conduct. However, these codes are still rare and are inconsistent in their guidelines. Those that do exist are well intentioned but would benefit from greater scientific scrutiny and input. As an example of the current guidelines being applied, we evaluated the content of a regional policy developed in New South Wales, Australia (Table 1). Overall, many of their findings were consistent with the recommendations outlined above, especially in reference to minimizing air exposure and using barbless hooks. A more generic code was developed for British Columbia by the Canadian Government, but it provides little specific welfare information other than " handle all fish with care" (Fisheries and Oceans 
Table 1

New South Wales Council of Freshwater Anglers (NSWCFW) (http://www.freshwateranglers.com.au/) developed a Recreational Anglers Code of Conduct (Policy 8) for its members and other anglers

NSWCFW Recreational Anglers Code

of Conduct Animal Welfare Guidelines

Fish should be landed quickly to minimize damage and stress

Dispatching a caught fish should be undertaken quickly and humanely by a blow to the head or spiking through the brain just behind the eye

Tethering of fish for any purposes is an unacceptable practice

The use of small barbless hooks is recommended for use where fish are to be released

Soft knotless landing nets are recommended for use where fish are to be released

When releasing a fish, keep it in the water, handle as little as possible with wet hands, carefully remove the hook, and walk the fish upright to regain its balance before allowing it to swim off

All fish bleeding from hooked gills should be killed as they will not survive

If lifting a fish to be released is unavoidable, support the fish's body weight with a horizontal lift using wet hands

Do not lift by the gills or tail

Where internal damage may result in hook removal from a fish to be released, the hook should be left undisturbed and the line cut as close as possible to the fish's mouth

The use of non-stainless steel hooks which rust and breakdown quickly are recommended
Commentary by Cooke and Sneddon on NSWCFW Guidelines

Agreed-see discussion and recommendation in this paper

Agree in principle - fish should be euthanized rapidly using accepted techniques; see AVMA (2001)

Agreed-see discussion about negative consequences associated with use of stringers; e.g., Cooke and Hogle (2000)

Agree in principle-see discussion above for our recommendation regarding use of barbless hooks, which is consistent with this guideline. However, hook size issues are poorly understood and require additional research; see Muoneke and Childress (1994),

Cooke et al. (2005)

Agree in principle-in some cases it is desirable to not use a net at all. Soft knotless nets and rubber nets both are good options

(Barthel et al., 2003). Recent innovations include tools that grip fish in the mouth may also be appropriate. Additional research is required as there is little scientific data regarding this topic

Agreed-this is consistent with our recommendation to keep fish in water and eliminate or minimize air exposure. Reviving fish can be helpful but should probably only be done by moving the fish forward through the water-the "forwards-backwards-forwards" technique may be detrimental as fish normally ventilate by taking in water from the mouth and expressing it under the opercula

This statement is not completely correct. First, not all bleeding will result in mortality, even in the gills. Second, lethal bleeding can occur from several areas in addition to the gills (such as the heart). The severity of the injury and the quantity of the blood must be considered. We are in agreement with the principle that a fish that is likely going to die should be retained

Agree in principle-however, there are no empirical data. Some fish (such as the centrarchids) can be restrained by gripping their lower jaw

Agree in principle-however, there are no empirical data Agree in principle-we still lack sufficient scientific data to make an informed decision for most situations (but see Schill, 1996). This will likely have to be a case specific assessment by the angler. Anglers should consider that option rather than adopt it uniformly

Agree in principle - we are aware of no scientific research on timing of hook breakdown in fish relative to material type, environment, hook size, species, hooking location, etc 
Table 1 (Continued)

\begin{tabular}{ll}
$\begin{array}{l}\text { NSWCFW Recreational Anglers Code } \\
\text { of Conduct Animal Welfare Guidelines }\end{array}$ & Commentary by Cooke and Sneddon on NSWCFW Guidelines \\
\hline $\begin{array}{ll}\text { Gaffs should only be used in } & \text { At present there is insufficient data on this topic. Barbless gaffs may } \\
\text { circumstances where a net is not } & \text { be appropriate for temporarily restraining fish. However, there are a } \\
\text { suitable due to the fish size and the } & \text { variety of techniques and tools that enable anglers to } \\
\text { fish is then quickly dispatched } & \text { release fish without use of gaffs }\end{array}$
\end{tabular}

The preamble to the code is as follows "In order that freshwater fishers gain the optimum continued enjoyment from this great recreational pursuit, it is necessary that one and all appreciate and abide by, not only the Department of Primary Industries (Fisheries)' regulations, but a Code of Practice that provides for the rights of individuals, animal welfare, preservation of the fishery and fish habitat, protection of the environment, protection wild fisheries, and respect for your fellow angler and other persons." Here, we reproduced the Animal Welfare Guidelines that they produced as part of their code and provide a commentary relative to our current scientific knowledge and our recommendations outlined in this paper.

Canada, 2001). Although regional guidelines are probably essential for ensuring that they are tailored to the specific fisheries, there are likely a series of more general guidelines that could be developed for global application (i.e., through the FAO). What is needed is a global code of conduct for recreational fishing that includes welfare considerations in addition to other typically included guidelines (e.g., respect for landowners rights, respect for the environment, etc.). Such a code could address issues from both a sustainability (Hickley, 1998; Cooke and Cowx, 2004), and welfare perspective. Such a document would complement the FAO Code of Conduct for Responsible Fisheries (FAO, 1995), which in its current form, is focused primarily on the commercial fishing sector.

\section{Conclusions}

Previous ideas that fish are incapable of perceiving pain and suffering (i.e., Rose, 2002) need revision in light of new scientific observations and reviews (Chandroo et al., 2004a,b). The fact that fish have the neuroanatomical attributes in terms of receptors and axons normally associated with nociception in higher vertebrates, makes it likely that fish are capable of perceiving painful stimuli. Behavioural analysis demonstrated aversive behavioural consequences from noxious stimulation consistent with the perception of painful stimuli interacting with central drivers of normal behaviour. Injuries are common occurrences in the procedures associated with recreational catch-and-release fisheries (Muoneke and Childress, 1994). The damage and potential resultant pain may affect subsequent behaviour such that foraging and predator avoidance may be impaired increasing the likelihood of reduced growth and mortality. Although we do not suggest that these potentially painful experiences are directly responsible for any mortality, they may contribute to the stress and fatigue caused by the fishing procedure. Injuries also leave fish susceptible to disease (e.g., Steeger et al., 1994) and stress impairs immune function (Mazeaud et al., 1977). Research should be directed at the role pain may play in fish welfare after release. Even if we determine in the future that our current understanding of the capacity of fish to feel pain and experience suffering was flawed, the benefits associated with improving catch-and-release angling will be immense.

A critical issue that is being addressed is the modification of fishing gear to minimize damage to angled fish. Efforts are also being devoted to develop new strategies or refine existing ones to improve angling practices and our understanding of the factors that contribute to fish injury, stress, and mortality (Muoneke and Childress, 1994; Cooke and Suski, 2005). Extending these 
assessments and our thinking of catch-and-release issues to include "pain and fear" is not difficult, as reducing injury and stress will directly improve welfare (Moberg, 1985). Although there are aspects of the catch-and-release angling experience that cannot be refined (e.g., the need to physically hook the fish), we argue that there are many choices that informed anglers and fisheries managers can make to improve the welfare of angled fish. Of course, there will be tough questions ahead as we are faced with challenges of determining what level of impact on an individual is appropriate and what to do if and when there are no ways to ameliorate the effects of angling on a fish. Furthermore, research results are often contradictory and sometimes use endpoints such as mortality, but ignore sublethal impacts that are relevant to welfare. For example, Schill and Scarpella (1997) conducted a meta-analysis and reported that for nonanadromous salmonids, barbless hooks reduced mortality by only $0.3 \%$ relative to barbed hooks, which they determined to be a meaningless difference at the population level. As such, they concluded that barbed hook restrictions represent a social issue and not a biological one. We would argue that this could be still viewed as a biological and definitely an animal welfare issue since there are more endpoints than mortality (e.g., degree of injury, bleeding, handling time and associated physiological disturbances, etc.).

Natural resource agencies and fisheries managers have the opportunity to influence choice of gears and practices through management regulations, education programming, and outreach activities. Thus, these agencies and individuals have the potential to encourage or require adoption of strategies that improve fish welfare. A recent study (Schupplid, 1999) evaluated the provincial fishing regulations across Canada to determine if the regulations were consistent with animal welfare principles. This author considered movement towards mandatory barbless hook regulations and live bait restrictions or detailed information on fish handling techniques reported in regulations booklets to be favorable for animal welfare. Management agencies in some provinces have made progress in fish welfare relative to an earlier analysis (AWFC, 1996), but the author concluded that there was still much room for improvement. We compared the recommendations and regulations utilized in different Canadian jurisdictions (as summarized by Schupplid, 1999) with findings from our review above (see Table 2). This analysis revealed that although there were some promising trends (e.g., all jurisdictions recommend anglers should keep fish in water), most regulations and guidelines that would improve fish welfare were not consistently applied or encouraged across jurisdictions (e.g., prohibition of stringers, mandatory use of barbless hooks; Table 2). In addition to governments, outdoor media, fishing guides, and fishing gear manufacturers also have the potential to improve fish welfare by educating anglers about gear and practices that benefit fish.

Although consideration of fish welfare is somewhat abstract to most anglers and fisheries managers, ultimately it benefits the individual fish, while simultaneously benefiting the sustainability of fish populations and fisheries. Indeed, it is vital to release fish that are in good condition so that they are able to survive and reproduce and experience no undue welfare impacts. Stakeholders must not be myopic, rather adopting broader views when considering and interpreting the complexities associated with catch-and-release angling ethics. We leave that debate to other outlets (e.g., see dialogue in the journal "Environmental Ethics"; de Leeuw, 1996; Chipeniuk, 1997; List, 1997). We believe that research by scientists, industry, and anglers has the potential to further minimize the effects of catch-andrelease fishing on individual fish and fisheries. Greater integration of welfare consideration into recreational (and commercial) fisheries should promote innovative solutions to minimize pain and suffering, which should also enhance conservation and management of recreational fisheries. 
Table 2

Summary of selected guidelines and regulations associated with catch-and-release angling in Canada

\begin{tabular}{|c|c|c|}
\hline Regulations or guidelines & $\begin{array}{l}\text { Number of } \\
\text { jurisdictions }\end{array}$ & Commentary by Cooke and Sneddon \\
\hline Barbless hooks recommended & 11 & $\begin{array}{l}\text { Consistent with our conclusions and most research findings. } \\
\text { Interestingly, few jurisdictions mandate their use (see below). } \\
\text { Thus, it is unclear how common barbless hook use is when } \\
\text { it is only recommended }\end{array}$ \\
\hline $\begin{array}{l}\text { Barbless hooks mandated } \\
\quad \text { (always) }\end{array}$ & 2 & \\
\hline $\begin{array}{l}\text { Barbless hooks mandated } \\
\quad \text { (some species) }\end{array}$ & 1 & \\
\hline $\begin{array}{l}\text { Barbless hooks mandated } \\
\quad \text { (some areas) }\end{array}$ & 5 & \\
\hline $\begin{array}{l}\text { Cut line if deeply hooked } \\
\text { (recommended) }\end{array}$ & 13 & $\begin{array}{l}\text { Although recommended, there is insufficient data on this topic. } \\
\text { We suggested that this is a case-by-case decision required } \\
\text { by the angler }\end{array}$ \\
\hline $\begin{array}{l}\text { Avoid contact with } \\
\text { gills or eyes } \\
\text { (recommended) }\end{array}$ & 12 & $\begin{array}{l}\text { Minimal handling would likely be best for the fish. No } \\
\text { specific data on this issue. We support this type of general } \\
\text { handling guideline }\end{array}$ \\
\hline $\begin{array}{l}\text { Play fish minimally } \\
\text { (recommended) }\end{array}$ & 11 & $\begin{array}{l}\text { Consistent with our findings above. However, not mandatory. } \\
\text { Would be difficult to enforce if it were mandatory. Positive } \\
\text { step to see this being included in recommendations }\end{array}$ \\
\hline $\begin{array}{l}\text { Keep fish in water } \\
\text { (recommended) }\end{array}$ & 14 & $\begin{array}{l}\text { Consistent with findings above. However, not mandatory. } \\
\text { Would be difficult to enforce if it were mandatory. This is the } \\
\text { only recommendation that has been adopted across all } \\
\text { jurisdictions. Although management agencies recognize the } \\
\text { importance of reducing air exposure, we are unsure how } \\
\text { much anglers are really doing to conform to this } \\
\text { recommendation }\end{array}$ \\
\hline Keep injured fish where legal & 5 & $\begin{array}{l}\text { Consistent with our findings above if it is severe injury. } \\
\text { It does not make sense to return fish to the water that will } \\
\text { inevitably die. That said, we would argue that every fish is } \\
\text { injured to some degree and not all of these should be kept. } \\
\text { Instead, severity of injury is important }\end{array}$ \\
\hline $\begin{array}{l}\text { Use knotless nets } \\
\text { (recommended) }\end{array}$ & 4 & $\begin{array}{l}\text { Consistent with findings above (e.g., Barthel et al., 2003). } \\
\text { Note that few jurisdictions have such as guideline }\end{array}$ \\
\hline Stringers prohibited & 3 & $\begin{array}{l}\text { Consistent with findings above (e.g., Cooke and Hogle, 2000). } \\
\text { Note that few jurisdictions have such regulations }\end{array}$ \\
\hline $\begin{array}{l}\text { Raise fish slowly from depth } \\
\text { (recommended) }\end{array}$ & 2 & $\begin{array}{l}\text { Consistent with literature suggesting fish from depth can } \\
\text { experience negative effects }\end{array}$ \\
\hline $\begin{array}{l}\text { Risk of fishing at warm } \\
\text { temperatures } \\
\text { (general information) }\end{array}$ & 2 & $\begin{array}{l}\text { Surprisingly few jurisdictions inform anglers of the role of } \\
\text { water temperature. Since 1999, the role of water temperature } \\
\text { in catch-and-release angling has been elucidated } \\
\text { so this likely has increased relevance today }\end{array}$ \\
\hline
\end{tabular}

Data are extracted from a 1999 Canadian assessment using regulations booklets developed for anglers (Schupplid, 1999). In total, 14 jurisdictions were evaluated including all 12 provinces and territories (note that Nunavut was not yet recognized as a territory in 1999), as well as National Parks and the coastal waters of British Columbia. Guidelines and regulations listed are those that we would believe have relevance to the welfare of angled fish. We provide a brief commentary on these findings with comment on the degree to which these regulations or guidelines are adopted by different jurisdictions. 


\section{Acknowledgements}

Several anonymous referees commented on the manuscript. Earlier comments were kindly provided by Tony Goldberg. SJC was funded by an NSERC and Izaak Walton Killam PostDoctoral Fellowship. LUS was funded on a NERC fellowship and a BBSRC Research Grant.

\section{References}

Aalbers, S.A., Stutzer, G.M., Drawbridge, M.A., 2004. The effects of catch-and-release angling on the growth and survival of juvenile white seabass captured on offset circle and J-type hooks. N. Am. J. Fish. Manage. 24, 793-800.

Aas, Ø., Thailing, C.E., Ditton, R.B., 2002. Controversy over catch-and-release recreational fishing in Europe. In: Pitcher, T.J., Hollingworth, C. (Eds.), Recreational Fisheries: Ecological, Economic, and Social Evaluation. Blackwell Science, United Kingdom, pp. 95-106.

AFS (American Fisheries Society), AIFRB (American Institute of Fishery Research Biologists), ASIH (American Society of Ichthyologists and Herpetologists), 2004. Guidelines for the Use of Fishes in Research. Amercian Fisheries Society, Betheda, MD., http://www.fisheries.org/html/Public_Affairs/Sound_Science/Guidelines2004.shtml.

Anderson, W.G., Booth, R., Beddow, T.A., McKinley, R.S., Finstad, B., Økland, F., Scruton, D., 1998. Remote monitoring of heart rate as a measure of recovery in angled Atlantic salmon, Salmo salar (L.). Hydrobiologia 371/372, 233240.

Appleby, M.C., 1999. What Should we do About Animal Welfare? Blackwell Science, Oxford, p. 192.

AVMA (American Veterinary Medical Association), 2001. Report of the AVMA panel on euthanasia. J. Am. Vet. Med. Assoc. 218, 670-696.

AWFC (Animal Welfare Foundation of Canada), 1996.In: A Report and Summary on Sport Fishing Regulations in Canada with Specific Reference to Humane Considerations, Animal Welfare Foundation of Canada, Vancouver, BC, p. 24.

Balon, E.K., 2000. Defending fishes against recreational fishing: an old problem to be solved in the new millennium. Environ. Biol. Fish. 57, 1-8.

Barthel, B.L., Cooke, S.J., Suski, C.D., Philipp, D.P., 2003. Effects of landing net mesh type on injury and mortality in a freshwater recreational fishery. Fish. Res. 63, 275-282.

Borucinska, J., Martin, J., Skomal, G., 2001. Peritonitis and pericarditis associated with gastric perforation by a retained fishing hook in a blue shark. J. Aquat. Anim. Health. 13, 347-354.

Borucinska, J., Kohler, N., Natanson, L., Skomal, G., 2002. Pathology associated with retained fishing hooks in blue sharks, Prionace glauca (L.), with implications for their conservation. J. Fish. Dis. 25, 515-521.

Booth, R.K., Kieffer, J.D., Davidson, K., Bielak, A.T., Tufts, B.L., 1995. Effects of late-season catch and release angling on anaerobic metabolism, acid-base status, survival and gamete viability in wild Atlantic salmon (Salmo salar). Can. J. Fish. Aquat. Sci. 52, 283-290.

Burns, K.M., Restrepo, V., 2002. Survival of reef fish after rapid depressurization: field and laboratory studies. Am. Fish. Soc. Symp. 30, 148-151.

Chandroo, K.P., Yue, S., Moccia, R.D., 2004a. An evaluation of current perspectives on consciousness and pain in fishes. Fish. Fish. 5, 281-295.

Chandroo, K.P., Duncan, I.J.H., Moccia, R.D., 2004b. Can fish suffer? Perspectives on sentience, pain, fear and stress. Appl. Anim. Behav. Sci. 86, 225-250.

Chipeniuk, R., 1997. On contemplating the interests of fish. Environ. Ethics. 19, 331-332.

Chopin, F.S., Arimoto, T., 1995. The condition of fish escaping from fishing gears-a review. Fish. Res. 21 , 315-327.

Collins, M.R., McGovern, J.C., Sedberry, G.R., Meister, H.S., Pardieck, R., 1999. Swim bladder deflation in black sea bass and vermilion snapper: potential for increasing postrelease survival. N. Am. J. Fish. Manage. 19, 828-832.

Conte, F.S., 2004. Stress and the welfare of cultured fish. Appl. Anim. Behav. Sci. 86, 205-223.

Cooke, S.J., Barthel, B.L., Suski, C.D., Siepker, M.J., Philipp, D.P., 2005. Influence of circle hook size on hooking efficiency and size selectivity with comments on circle hook conservation benefits in a recreational bluegill fishery. $\mathrm{N}$. Am. J. Fish. Manage. 25, 211-219.

Cooke, S.J., Bunt, C.M., Ostrand, K.G., Philipp, D.P., Wahl, D.H., 2004. Angling-induced cardiac disturbance of freeswimming largemouth bass (Micropterus salmoides) monitored with heart rate telemetry. J. Appl. Ichthyol. 20, 28-36.

Cooke, S.J., Cowx, I.G., 2004. The role of recreational fisheries in global fish crises. BioScience 54, 857-859.

Cooke, S.J., Hogle, W.J., 2000. Effects of retention gear on the injury and short-term mortality of adult smallmouth bass. N. Am. J. Fish. Manage. 20, 1033-1039. 
Cooke, S.J., Philipp, D.P., 2004. Behavior and mortality of caught-and-released bonefish (Albula spp) in Bahamian waters with implications for a sustainable recreational fishery. Biol. Conserv. 118, 599-607.

Cooke, S.J., Philipp, D.P., Dunmall, K.M., Schreer, J.F., 2001. The influence of terminal tackle on injury, handling time, and cardiac disturbance of rock bass. N. Am. J. Fish. Manage. 21, 333-342.

Cooke, S.J., Philipp, D.P., Schreer, J.F., McKinley, R.S., 2000. Locomotory impairment of nesting male largemouth bass following catch-and-release angling. N. Am. J. Fish. Manage. 20, 968-977.

Cooke, S.J., Schreer, J.F., Dunmall, K.M., Philipp, D.P., 2002a. Strategies for quantifying sublethal effects of marine catch-and-release angling_insights from novel freshwater applications. Am. Fish. Soc. Symp. 30, $121-134$.

Cooke, S.J., Schreer, J.F., Wahl, D.H., Philipp, D.P., 2002b. Physiological impacts of catch-and-release angling practices on largemouth bass and smallmouth bass. Am. Fish. Soc. Symp. 31, 489-512.

Cooke, S.J., Suski, C.D., 2004. Are circle hooks effective tools for conserving freshwater and marine recreational catchand-release fisheries? Aquat. Conserv. Mar. Freshwater Ecosyst. 14, 299-326.

Cooke, S.J., Suski, C.D., 2005. Do we need species-specific guidelines for catch-and-release recreational angling to conserve diverse fishery resources? Biodiver. Conserv. 14, 1195-1209.

Cooke, S.J., Suski, C.D., Barthel, B.L., Ostrand, K.G., Tufts, B.L., Philipp, D.P., 2003. Injury and mortality induced by four hook types on bluegill and pumpkinseed. N. Am. J. Fish. Manage. 23, 883-893.

Cowx, I.G., 2002. Recreational fisheries. In: Hart, P.B.J., Reynolds, J.D. (Eds.), Handbook of Fish Biology and Fisheries, vol. II. Blackwell Science, Oxford, pp. 367-390.

Dawkins, M.S., 1998. Evolution and animal welfare. Quart. Rev. Biol. 73, 305-328.

de Leeuw, A.D., 1996. Contemplating the interests of fish: the angler's challenge. Environ. Ethics 18, 373-390.

DFO (Department of Fisheries and Oceans), 2003. Summary of 2000 recreational fishing statistics in Canada. Ottawa, Canada. (20 January 2004; http://www.dfo-mpo.gc.ca/communic/statistics/RECFISH/new2002/sum2000_e.HTM).

DeTolla, L.J., Srinivas, S., Whitaker, B.R., Andrews, C., Hecker, B., Kane, A.S., Reimschessel, R., 1995. Guidelines for the care and use of fish in research. ILAR J. 37, 1-20.

Diggles, B.K., Ernst, I., 1997. Hooking mortality of two species of shallow-water reef fish caught by recreational angling methods. Mar. Freshw. Res. 48, 479-483.

DuBois, R.B., Dubielzig, R.R., 2004. Effect of hook type on mortality, trauma, and capture efficiency of wild stream trout caught by angling with spinners. N. Am. J. Fish. Manage. 24, 609-616.

DuBois, R.B., Kuklinski, K.E., 2004. Effect of hook type on mortality, trauma, and capture efficiency of wild, streamresident trout caught by active baitfishing. N. Am. J. Fish. Manage. 24, 617-623.

Dunlop, R., Laming, P., 2005. Mechanoreceptive and nociceptive responses in the central nervous system of goldfish (Carassius auratus) and trout (Oncorhynchus mykiss). J. Pain 6, 561-568.

Dunmall, K.M., Cooke, S.J., Schreer, J.F., McKinley, R.S., 2001. The effect of scented lures on the hooking injury and mortality of smallmouth bass caught by novice and experienced anglers. N. Am. J. Fish. Manage. 21, 242248.

Erickson, H.S., 2003. Information resources on fish welfare. AWIC Resource Series 20. (http://www.//nal.usda.gov/awic/ pubs/Fishwelfare/fishwelfare.htm).

FAO (Food and Agriculture Organization of the United Nations), 1995. Code of Conduct for Responsible Fisheries. FAO, Rome, p. 41 Available from: http://www.fao.org/fi/agreem/codecond/codecon.asp.

FAO (Food and Agriculture Organization of the United Nations), 1997. Inland Fisheries. FAO Fisheries Department Technical Guidelines for Responsible Fisheries No 6 (Technical guidelines for the sustainable management of inland fisheries). FAO, Rome.

Ferguson, R.A., Tufts, B.L., 1992. Physiological effects of brief air exposure in exhaustively exercised rainbow trout (Oncorhynchus mykiss): Implications for "catch and release" fisheries. Can. J. Fish. Aquat. Sci. 49, 11571162 .

Fisheries and Oceans Canada, 2001. Code of Conduct for Sportfishing in British Columbia. Sport Fishing Advisory Board, Fisheries and Oceans Canada, Vancouver, BC. , In: http://www-comm.pac.dfo-mpo.gc.ca/pages/sfg/general/ conduct_e.htm.

Fry, F.E.J., 1971. The effect of environmental factors on the physiology of fish. In: Hoar, W.S., Randall, D.J. (Eds.), Fish Physiology, Environmental Relations and Behavior, vol. VI. Academic Press, New York, pp. 1-98.

FSBI (Fisheries Society of the British Isles), 2002. Fish welfare. Briefing Paper 2, Fisheries Society of the British Isles. Available From: Granta Information Systems, 82A High Street, Sawston, Cambridge, CB2 4H, UK.

Gentle, M.J., 1992. Pain in birds. Anim. Welfare 1, 235-247.

Gentle, M.J., 2001. Attentional shifts alter pain perception in the chicken. Anim. Welfare 10, S187-S194.

Gustaveson, A.W., Wydowski, R.S., Wedemeyer, G.A., 1991. Physiological response of largemouth bass to angling stress. Trans. Am. Fish. Soc. 120, 629-636. 
Hickley, P., 1998. Comments concerning a code of good practice for recreational fishing. In: Hickley, P., Tompkins, H. (Eds.), Recreational Fisheries: Social, Economic and Management Aspects. Fishing News Books. Blackwell Science, Oxford, pp. 299-304.

Hickley, P., Tompkins, H. (Eds.), 1998. Social Economic and Management Aspects of Recreational Fisheries. Fishing News Books. Blackwell Science, Oxford.

Iwama, G.K., Sumpter, J., Pickering, A.D., Schreck, C.B. (Eds.), 1997. Fish stress and health in Aquaculture. Society for Experimental Biology Seminar Series 62. Cambridge University Press, Cambridge, UK.

Kato, Y., Kowalski, C.J., Stohler, C.S., 2001. Habituation of the early pain-specific respiratory response in sustained pain. Pain 91, 57-63.

Kavaliers, M., Colwell, D.D., 1991. Sex differences in opioid and non-opioid mediated predator-induced analgesia in mice. Brain Res. 568, 173-177.

Keniry, M.J., Brofka, W.A., Horns, W.H., Marsden, J.E., 1996. Effects of decompression and puncturing the gas bladder on survival of tagged yellow perch. N. Am. J. Fish. Manage. 16, 201-206.

Kerr, S.J., 2001. A Review of "Fizzing"-A Technique for Swim Bladder Deflation. Ontario Ministry of Natural Resources, Peterborough, ON.

Kieffer, J.D., 2000. Limits to exhaustive exercise in fish. Comp. Biochem. Physiol. 126A, 161-179.

Kieffer, J.D., Kubacki, M.R., Phelan, F.J.S., Philipp, D.P., Tufts, B.L., 1995. Effects of catch and release angling on nesting male smallmouth bass. Trans. Am. Fish. Soc. 124, 70-76.

Kuhajda, M.C., Thorn, B.E., Kilinger, M.R., 1998. The effect of pain on memory for affective words. Ann. Behav. Med. 20, 1-5.

Laitinen, M., Valtonen, T., 1994. Cardiovascular, ventilatory and total activity responses of brown trout to handling stress. J. Fish Biol. 45, 933-942.

Lawson, P.W., Sampson, D.B., 1996. Gear-related mortality in selective fisheries for ocean salmon. N. Am. J. Fish. Manage. 16, 512-520.

Lindsay, R.B., Schroeder, R.K., Kenaston, K.R., Toman, R.N., Buckman, M.A., 2004. Hooking mortality by anatomical location and its use in estimating mortality of spring Chinook salmon caught and released in a river sport fishery. N. Am. J. Fish. Manage. 24, 367-378.

List, C.J., 1997. On angling as an act of cruelty. Environ. Ethics. 19, 333-334.

Lowerre-Barbieri, S.K., Vose, F.E., Whittington, J.A., 2003. Catch-and-release fishing on a spawning aggregation of common snook: does it affect reproductive output? Trans. Am. Fish. Soc. 132, 940-952.

Mazeaud, M.M., Mazeaud, F., Donaldson, E.M., 1977. Primary and secondary effects of stress in fish: some new data with a general review. Trans. Am. Fish. Soc. 106, 201-212.

McPhee, D.P., Leadbitter, D., Skilleter, G.A., 2002. Swallowing the bait: is recreational fishing ecologically sustainable? Pacific Conserv. Biol. 8, 40-51.

Meka, J.M., 2004. The influence of hook type, angler experience, and fish size on injury rates and the duration of capture in an Alaskan catch-and-release rainbow trout fishery. N. Am. J. Fish. Manage. 24, 1309-1321.

Meka, J.M., McCormick, S.D., 2005. Physiological response of wild rainbow trout to angling: Impact of angling duration, fish size, body condition, and temperature. Fish. Res. 72, 311-322.

Moberg, G.P., 1985. Biological response to stress: key to assessment of animal well-being. In: Moberg, G.P. (Ed.), Animal Stress. American Physiological Society, Bethesda, pp. 27-49.

Molony, V., Kent, J.E., McKendrick, I.J., 2002. Validation of a method for assessment of acute pain in lambs. Appl. Anim. Behav. Sci. 76, 215-238.

Morrissey, M.B., Suski, C.D., Esseltine, K.R., Tufts, B.L., 2005. Incidence and physiological consequences of impacts of decompression in smallmouth bass after live-release angling tournaments. Trans. Am. Fish Soc. 134, $1038-1047$.

Muoneke, M.I., Childress, W.M., 1994. Hooking mortality: a review for recreational fisheries. Rev. Fish. Sci. 2, $123-156$.

Ostrand, K.G., Cooke, S.J., Wahl, D.H., 2004. Effects of stress on largemouth bass reproduction. N. Am. J. Fish. Manage. 24, 1038-1045.

Pankhurst, N.W., Dedual, M., 1993. Effects of capture and recovery on plasma levels of cortisol, lactate and gonadal steroids in a natural population of rainbow trout. J. Fish Biol. 45, 1013-1025.

Pankhurst, N.W., Van Der Kraak, G., 1997. Effects of stress on reproduction and growth of fish. In: Iwama, G.K., Sumpter, J., Pickering, A.D., Schreck, C.B. (Eds.), Fish Stress and Health in Aquaculture. Society for Experimental Biology Seminar Series, 62. Cambridge University Press, Cambridge, UK, pp. 73-95.

Pauley, G.B., Thomas, G.L., 1993. Mortality of anadromous coastal cutthroat trout caught with artificial lures and natural bait. N. Am. J. Fish. Manage. 13, 337-345.

Pelzman, R.J., 1978. Hooking mortality of juvenile largemouth bass, Micropterus salmoides. Calif. Fish. Game. 64, 185188. 
Philipp, D.P., Toline, C.A., Kubacki, M.F., Philipp, D.B.F., Phelan, F.J.S., 1997. The impact of catch-and-release angling on the reproductive success of smallmouth bass and largemouth bass. N. Am. J. Fish. Manage. 17, 557-567.

Pitcher, T.J., Hollingworth, C., 2002a. Recreational Fisheries: Ecological, Economic and Social Evaluation. Blackwell Science, Oxford, UK, p. 271.

Pitcher, T.J., Hollingworth, C.E., 2002b. Fishing for fun: where's the catch? In: Pitcher, T.J., Hollingworth, C.E. (Eds.), Recreational Fisheries: Ecological, Economic and Social Evaluation. Blackwell Science, Oxford, UK, pp. $1-16$.

Policansky, D., 2002. Catch-and-release recreational fishing: a historical perspective. In: Pitcher, T.J., Hollingworth, C.E. (Eds.), Recreational Fisheries: Ecological, Economic and Social Evaluation. Blackwell Science, Oxford, pp. 74-94.

Pope, K.L., Wilde, G.R., 2004. Effect of catch-and-release angling on growth of largemouth bass, Micropterus salmoides. Fish. Manage. Ecol. 11, 39-44.

Portavella, M., Vargas, J.P., Torres, B., Salas, C., 2002. The effects of telencephalic pallial lesions on spatial, temporal, and emotional learning in goldfish. Brain Res. Bull. 57, 397-399.

Pottinger, T.G., 1997. Changes in water quality within anglers' keepnets during the confinement of fish. Fish. Manage. Ecol. 4, 341-354.

Prince, E.D., Ortiz, M., Venizelos, A., 2002. A comparison of circle hook and "J" hook performance in recreational catchand-release fisheries for billfish. Am. Fish. Soc. Symp. 30, 66-79.

Quinn, S., 1993. Hands on catch and release controversy. Fisherman 18, 36-44.

Quinn, S., 1996. Trends in regulatory and voluntary catch-and-release fishing. Am. Fish. Soc. Symp. 16, $152-162$.

Raat, A.J.P., Klein-Breteler, J.G.P., Jansen, S.A.W., 1997. Effects on growth and survival of retention of rod-caught cyprinids in large keepnets. Fish. Manage. Ecol. 4, 355-368.

Radonski, G.C., 2002. History and application of catch-and-release fishing: The good, the bad, and the ugly. Am. Fish. Soc. Symp. 30, 3-10.

Randerson, J., 2003. Does a hook hurt a fish? The evidence is reeling in. New Scientist May: 15.

Robb, D.F.H., Kestin, S.C., 2002. Methods used to kill fish: field observations and literature reviewed. Anim. Welf. 11, 269-282.

Rose, J.D., 2002. The neurobehavioral nature of fishes and the question of awareness and pain. Rev. Fish. Sci. 10, 1-38.

Roveroni, R.C., Parada, C.A., Cecilia, M., Veiga, F.A., Tambeli, C.H., 2001. Development of a behavioural model of TMJ pain in rats: the TMJ formalin test. Pain 94, 185-191.

Savitz, J., Bardygula-Nonn, L.G., Simpson, A., Funk, G., 1995. Survival of smaller sport caught chinook, Oncorhynchus tshawytscha (Walbaum), and coho, Oncorhynchus kisutch (Walbaum), salmon from Lake Michigan and its management implications. Fish. Manage. Ecol. 2, 11-16.

Schaeffer, J.S., Hoffman, E.M., 2002. Performance of barbed and barbless hooks in a marine recreational fishery. N. Am. J. Fish. Manage. 22, 229-235.

Schill, D.J., 1996. Hooking mortality of bait-caught rainbow trout in an Idaho trout stream and a hatchery: Implications for special-regulation management. N. Am. J. Fish. Manage. 16, 348-356.

Schill, D.J., Scarpella, R.L., 1997. Barbed hook restrictions in catch-and-release trout fisheries: a social issue. N. Am. J. Fish. Manage. 17, 873-881.

Schisler, G.J., Bergersen, E.P., 1996. Postrelease hooking mortality of rainbow trout caught on scented artificial baits. N. Am. J. Fish. Manage. 16, 570-578.

Schreer, J.F., Cooke, S.J., McKinley, R.S., 2001. Cardiac response to variable forced exercise at different temperaturesan angling simulation for smallmouth bass. Trans. Am. Fish. Soc. 130, 783-795.

Schupplid, C.A., 1999. Report and Recommended Actions for Humane Angling in Canada. Prepared for the Animal Welfare Foundation of Canada, Vancouver, BC, p. 23.

Siepker, M., 2004. Effects of recreational angling on black bass. M.Sc. Thesis. Department of Natural Resources and Environmental Sciences, University of Illinois, Urbana, IL.

Sneddon, L.U., 2002. Anatomical and electrophysiological analysis of the trigeminal nerve in the rainbow trout, Oncorhynchus mykiss. Neurosci. Lett. 319, 167-171.

Sneddon, L.U., 2003a. Trigeminal somatosensory innervation of the head of the teleost fish with particular reference to nociception. Brain Res. 972, 44-52.

Sneddon, L.U., 2003b. The evidence for pain in fish: the use of morphine as an analgesic. Appl. Anim. Behav. Sci. 83, 153-162.

Sneddon, L.U., 2004. Evolution of nociception in vertebrates: Comparative analysis of lower vertebrates. Brain Res. Rev. 46, 123-130.

Sneddon, L.U., Braithwaite, V.A., Gentle, M.J., 2003a. Do fish have nociceptors: evidence for the evolution of a vertebrate sensory system. Proc. R. Soc. Lond. B 270, 1115-1122. 
Sneddon, L.U., Braithwaite, V.A., Gentle, M.J., 2003b. Novel object test: examining nociception and fear in the rainbow trout. J. Pain 4, 431-440.

Sneddon, L.U., Gentle, M.J., 2002. Receptor types on the head of the rainbow trout: are nociceptors present? Comp. Biochem. Physiol. A 32 (Suppl. 1), S42.

Spitler, R.J., 1998. The animal rights movement and fisheries. Fisheries 23 (1), 21-22.

Spruijt, B.M., 1999. Do fish have feelings: a sensitive subject. In: Raat, A.P.J., van den Bos, R. (Eds.), Welfare of Fish. Tilburg University Press, Tilburg, The Netherlands, (in Dutch), pp. 91-98.

Stange, D., 2003. The simple and continuing sense in selective harvest. In-Fisherman Media, Brainerd, MN. See: (http:// www.in-fisherman.com/magazine/articles/if2902_AnglesHarvest/index.html).

Steeger, T.M., Grizzle, J.M., Weathers, K., Newman, M., 1994. Bacterial diseases and mortality of angler-caught largemouth bass released after tournaments on Walter F. George reservoir, Alabama/Georgia. N. Am. J. Fish. Manage. $14,435-441$.

Steffens, W., Winkel, M., 2002. Evaluating recreational fishing in Germany. In: Pitcher, T.J., Hollingworth, C.E. (Eds.), Recreational Fisheries: Ecological, Economic and Social Evaluation. Blackwell Science, Oxford, UK, pp. $130-136$.

Stevens, C.W., 1992. Alternatives to the use of mammals for pain research. Life Sci. 50, 901-912.

Stockwell, J.D., Diodati, P.J., Armstrong, M.P., 2002. A bioenergetic evaluation of the chronic stress hypothesis: can catch-and-release fishing constrain striped bass growth? Am. Fish. Soc. Symp. 30, 121-134.

Suski, C.D., Killen, S.S., Cooke, S.J., Kieffer, J.D., Philipp, D.P., Tufts, B.L., 2004. Physiological significance of the weigh-in during live-release angling tournaments for largemouth bass. Trans. Am. Fish. Soc. 133, 1291-1303.

Taylor, M.J., White, K.R., 1992. A meta-analysis of hooking mortality of nonanadromous trout. N. Am. J. Fish. Manage. $12,760-767$.

Thorstad, E.B., Næsje, T.F., Fiske, P., Finstad, B., 2003. Effects of hook and release on Atlantic salmon in the river Alta, northern Norway. Fish. Res. 60, 293-307.

Turek, S.M., Brett, M.T., 1997. Comment: trout mortality from baited barbed and barbless hooks (and reply). N. Am. J. Fish. Manage. 17, 807.

US Department of Commerce, 2002. Fisheries of the United States 2001. National Marine Fisheries Service, Fisheries Statistics and Economics Division, Silver Springs, Md.

van de Vis, H., Kestin, S., Robb, D., Oehlenschläger, J., Lambooij, B., Münker, W., Kuhlmann, H., Kloosterboer, K., Tejada, M., Huidobro, A., Otterå, H., Roth, B., Sørensen, N.K., Akse, L., Byrne, H., Nesvadba, P., 2003. Is humane slaughter of fish possible for industry? Aquacult. Res. 34, 211-220.

Wall, A.J., 2001. Ethical considerations in the handling and slaughter of farmed fish. In: Kestin, S.C., Warriss, P.D. (Eds.), Farmed Fish Quality. Blackwell Science, Oxford, pp. 108-115.

Warner, K., 1976. Hooking mortality of landlocked Atlantic salmon, Salmo salar, in a hatchery environment. Trans. Am. Fish. Soc. 105, 365-369.

Wells, R.M.G., McIntyre, R.H., Morgan, A.K., Davie, P.S., 1986. Physiological stress responses in big gamefish after capture: observations on plasma chemistry and blood factors. Comp. Biochem. Physiol. 84A, 565-571.

Wilde, G.R., 1998. Tournament-associated mortality in black bass. Fisheries 23 (10), 12-22.

Wilde, G.R., Muoneke, M.I., Bettoli, P.W., Nelson, K.L., Hysmith, B.T., 2000. Bait and temperature effects on striped bass hooking mortality in freshwater. N. Am. J. Fish. Manage. 20, 810-815.

Wilde, G.R., Pope, K.L., Strauss, R.E., 2003. Estimation of fishing-tournament mortality and its sampling variance. N. Am. J. Fish. Manage. 23, 779-786.

Wilkie, M.P., Davidson, K., Brobbel, M.A., Kieffer, J.D., Booth, R.K., Bielak, A.T., Tufts, B.L., 1996. Physiology and survival of wild Atlantic salmon following angling in warm summer waters. Trans. Am. Fish. Soc. 125, 572580 .

Wilkie, M.P., Brobbel, M.A., Davidson, K., Forsyth, L., Tufts, B.L., 1997. Influences of temperature upon the postexercise physiology of Atlantic salmon (Salmo salar). Can. J. Fish. Aquat. Sci. 54, 503-511.

Wood, C.M., 1991. Acid-base and ion balance, metabolism, and their interactions, after exhaustive exercise in fish. J. Exp. Biol. 160, 285-308.

Wood, C.M., Turner, J.D., Graham, M.S., 1983. Why do fish die after severe exercise? J. Fish. Biol. 22, $189-201$.

Wydoski, R.S., 1977. Relation of hooking mortality and sublethal hooking stress to quality fishery management. In: Barnhart, R.A., Roelofs, T.D. (Eds.), Catch-and-Release Fishing as a Management Tool. Humbolt State University, Arcata, California, pp. 43-87.

Yue, S., Moccia, R.D., Duncan, I.J.H., 2004. Investigating fear in domestic rainbow trout, Oncorhynchus mykiss, using an avoidance learning task. Appl. Anim. Behav. Sci. 87, 343-354.

Zimmerman, M., 1986. Physiological mechanisms of pain and its treatment. Klinische Anäesthesiol. Intensivtherapie. 32, 1-19. 